\title{
Wages for Women Workers
}

\section{By Mary Anderson}

WOMEN are doing their share of our country's work under many new conditions and it therefore becomes a national responsibility to see that they are not sacrificed or exploited.

\section{Equal Work, Equal Pay}

Women's wages should be determined in the same manner as men's wages. As Miss Mary Van Kleeck, Director of the Woman in Industry Service of the Department of Labor has well said, "Wages should be determined on the basis of occupation and not on the basis of sex." Women doing the same work as men should receive the same wages with such proportionate increases as the men are receiving in the same industry. Slight changes made in the process or in the arrangement of work should not be regarded as justifying a lower wage for a woman than for a man unless statistics of production show that the output for the job in question is less when women are employed than when men are employed. If a difference in output is demonstrated, the difference in the wage rate should be based upon the difference in production for the job as a whole and not determined arbitrarily.

During the period of the war, employers have been outspoken in their praises of women's work. They have said very truthfully that the women who have taken men's places have been just as efficient and in many instances have done more and better work than the men whom they replaced or those with whom they worked side by side. But their attitude on wages has been curiously illogical.

For example, in one city a manufacturer with very important war contracts wanted to employ women for night work. In that state the law forbids the employment of women between the hours of ten p.m. and six a.m. The employer gave as his reasons for urging night work that women were far better workers than men, that they did more work and better work and came to the factory with greater regularity, that he had a night shift of men 
who were very inefficient and most of whose work had to be thrown on the scrap pile.

A casual inquiry was, "How much are you paying an hour for this work?"

"Oh," was the reply, "we are paying the men forty cents an hour with a fifteen per cent bonus for night work."

Another question was, "How much are you intending to pay the women for working at night?"

Answer: "We will pay them twenty-five cents an hour."

The query went forth again: "You have said women are more efficient than the men and that they do more work and better work. Don't you think that they ought to receive the same pay that these very inefficient men are getting?"

Reply: "But women have not the same family responsibility that men have."

Question: "But do you know how many of your men employes have family responsibilities?"

Reply: "Some do and some do not."

The same question was asked as to the women. He said that he had in his employ widows who had children dependent upon them and he admitted that girls probably had the same responsibility toward their families that young men have. "But," he said,"the manufacturers in this city are not paying the same wages to the women as to the men. If they did, it would bring on a revolution."

He was asked, "Have the employers an understanding that equality shall not prevail as to wages for men and women?"

His answer was, "Yes."

Statements are frequently made by employers that they are paying the same wage for the same work to women as to men. No doubt in many cases this is literally true, but more often the statement will not bear analysis. For example, one company, which is using women to do heavy hauling, claimed to be paying women the same money as the men, giving the rate as thirty-two and one-half cents an hour, but at the time the statement was made the rate for men was from forty to forty-two cents. Another statement, which is probably more typical, comes from a lumber operator who says, "The women receive the wages formerly paid to men for the same work." Paying women a wage at which men 
would not be available at the time is not in any sense equal pay for equal work.

The waitresses of a big middle-west city report similar discrimination. ${ }^{1}$ The waitresses' union had difficulty this year in signing up its contracts. The contracts contained a clause stating that where women were employed to take men's places and were doing an equal amount of work they must be paid an equal wage with the men. The employers admitted that they intended to fill vacancies left by men with women, that the work would be just the same for the women as for the men, and that they expected to get these women workers for three dollars a week less than they were paying the men. The secretary of this union was one day arguing the matter with a young man who manages a chain of restaurants.

"Supposing I should take your job," she said. "You know you are in the draft and you know, too, that I could take your place very nicely. How would you like to go away to war knowing that I was doing your work for a half or two-thirds the wages you are now getting? You would know for a certainty that when you come back from war you might get the job back, but you would get it back at my wages and not at the wages you are getting now. How would you like that, after you have made the sacrifice to go for the sake of your country? What kind of a patriot would I be to take that job and what kind of a patriot is the owner of your restaurants to try now to do this thing?"

Several departments of the federal government have taken a clear and definite stand on the question of wages for women. Director General of Railroads, McAdoo, issued the following order in May, 1918, affecting the employes of 164 railroads of the country:

When women are employed their working conditions must be healthful and fitted to their needs. The laws enacted for the government of their employment must be observed and their pay, when they do the same class of work as men, shall be the same as that of men.

The following statement is made by the Bureau of Labor Statistics of the United States Department of Labor:

The great danger from the viewpoint of health is that the employment of women should be resorted to merely in order to obtain cheap labor. As a matter of public health we must see to it that women are paid equal wages for equal work. Otherwise, their employment can be and is daily being made the excuse for undercutting the standard wages of men and so reducing the standards of living in the community. It is true that in many of the new occupations the women are unskilled and need training. Yet even while they are being trained, they should as a matter of health be paid an adequate wage.

\section{Arguments against Wage Increases the Same for Men and WOMEN}

Employers will advance the same arguments against wage increases for women that they have long used in opposing the demands of men workers. They will claim that regardless of the es-

1 From “Women's Work and the War," July, 1918. 
sential fairness of any wage increase that might be asked by the workers, the financial condition of the business will not stand the burden of a higher labor cost and that great consideration should be given to this fact; that it should, indeed, be the only factor in determining whether an increase should be given. However, a careful inquiry into the profits will often show that there is a large overhead expense, such as dividends paid in the form of large salaries, or dissipation by wasteful methods of the profits, leaving no money for increasing wages. The only way to obtain a thorough knowledge of what an industry can or cannot stand in the way of increased labor cost is to refer the whole matter to a court of arbitration.

In the arbitration of questions concerning wages and hours in the packing house industry, the packing firms did not give the usual testimony that the profits of the industry will not warrant a substantial increase in wages or that the highly competitive nature of the business would forbid the change. Obviously, this was because the workers and the people had been reading of the large dividends in this industry. The lawyers for the firm, in summing up the case, begged the arbitrator to have in mind, in considering this question, that granting this increase would create unrest and dissatisfaction in other industries paying less than the packing houses' employes would be receiving and, therefore, an increase should not be granted. The result of the arbitration was the establishment of the basic eight-hour day with time and one-half for overtime, double time for all work on Sundays and holidays, the same rate of pay for eight hours as was previously paid for ten hours with an additional increase in the hour rate and piece rate. Thus order instead of chaos was established in the packing industry.

Another claim frequently urged by the employers is that the amount of increase in wages adds directly to the expenses of the business and, therefore, automatically results in reduction in profits. This claim is based upon the assumption that the employer will have to pay a higher price for the same quality and the same amount of work that he obtained under the lower wage scale. That this assumption is erroneous has been conclusively proven by generations of industrial experience. Workers whose wages are low, hours of work long, working conditions poor, who 
must submit to ill treatment and constant nagging by the men and women directly in charge of the work, can render only poor and inefficient service. Those who are adequately paid and thereby better nourished, who have shorter hours which means lessened fatigue, who have self-government through shop committees and the right to take up the grievances that constantly arise between the foreman or forelady and the workers, do work of better quality and produce a greater output. Experience has proven that increases in the amount of the output and its improved quality entirely offset the increase in wages. This is illustrated in the case of Hart, Schaffner, and Marks, a large clothing firm employing about 8,000 people of whom about 63 per cent are women. During the first two years of the agreement between the firm and the union, wages had increased from 25 to 80 per cent, and at the same time profits were doubled. This was due to the increased efficiency of the workers which decreased to a large extent the need for sub-foremen and examiners and increased the volume of business because of better workmanship.

Some of the largest of our industries have voluntarily made large increases in wages against the protest of business competitors and associates who predicted that the effect would be the financial ruin of the industry. The practical results, however, completely refuted these predictions, for the expense per unit of production was very much decreased as a result of better service rendered, and profit to the employer showed the corresponding increase.

Another beneficial result of paying adequate wages that should be mentioned is the immediate decrease in the "labor turnover" which means the constant hiring of large numbers of workers to take the places of those who leave. The greatest number of employes leaving their place of employment can be found without a doubt in the establishments where wages are so low that men and women cannot maintain themselves and their families in health, thereby becoming a charge upon society as a whole through the medium of charitable organizations, in order to supply the difference between their actual wage and a living wage. This can at its best be done only in a very meager way for a limited time. It is conceded by all enlightened employers of labor that there is not only a large cost in constantly training people in an industry, but that there is also a decided reduction 
of product due to the continuous introduction of new and untrained workers. This very expensive process could be eliminated if the money and time spent in "hiring and firing" and training could be added to the wages of the employes.

Captain Boyd Fisher, who conducted courses of employment management for the United States Government, says:

One of the basic remedies for high labor turnover is the payment of an adequate wage. . . . By an adequate wage I do not mean the minimum wage. I mean a good fat wage. One that will clothe and educate their children as well as feed them properly.

\section{How to Handle Wage Questions Afrecting Men and WOMEN}

Wage questions affecting both men and women can best be handled by collective bargaining and by arbitration. The combination of these two methods means the application of sound democracy in the workshop. No one knows better than the trade unionists that the average wage-earner has had very little control over the conditions of his or her life, especially over that part of life which is the core of all the rest, the job. Collective bargaining means that the workers have got together, have elected their committee, let us say, have sent this committee to the employer, have been told there is nothing to discuss. The committee suggests arbitration. They are told there is nothing to arbitrate. The workers begin to understand that in industrial democracy they have no representation, that there is not actually industrial democracy. The National War Labor Board, by proclamation of the President, instituted collective bargaining in many cases where there was no organization. The first principle reads: "The right of workers to organize in trade-unions and to bargain collectively through chosen representatives is recognized and affirmed. This right shall not be denied, abridged, or interfered with by the emp oyers in any manner whatsoever." It is becoming clearer and clearer to all thinking men and women that we cannot have real democracy unless we have democracy in the workshop.

The arbitration policy that I am most familiar with is that instituted by the Boot and Shoe Workers International Union more than twenty years ago. It has been very successful, so much so that Brockton, Massachusetts, the largest shoe center in 
this country, has had no strikes or lockouts since this agreement was signed. The first firm that entered into this arbitration agreement was the W. L. Douglas Shoe Company of Brockton, Massachusetts, about twenty-one years ago. Many shoe firms, both in Brockton and other localities, have entered into similar agreements because they have seen the results of this policy of peace. Employers know that during the life of the agreement there will be no strikes and the employes know that there will be no lockout by the firm. They know that wages, hours of work and other working conditions which cannot be mutually agreed upon will be submitted to arbitration, and the decision that is reached will be final and binding upon the employer, the union and the employes.

For years, many people have thought of shortened hours of labor and of increases in wages from the standpoint of its meaning a few more dollars on pay day, and another hour or two that would not have to be spent in the factory. It is time to look at both of these as something more than a few more dollars on pay day and another hour or two out of the factory. It is something more than that. Wages determine life,-the standards of living, the health of body as well as of mind. The wages received determine where the worker shall live, whether in one room or two, in a cheap and crowded tenement district or in a home with pure air and sunshine. Wages will determine what kind of food can be had for families and that in turn determines the quality of children and the future citizenship. 